\title{
When Two Sisters Jointly Ruled an Empire
}

\author{
Valentine J. Belfiglio ${ }^{a}$
}

\begin{abstract}
This study will examine the ascent of two women as emperors of the Eastern Roman Empire within the context of constructivism and feminist international relations theory. Constructivism emphasizes ideas, such as the content of language and social discourse, over institutions or power. Feminism critiques international relations as a male-centered and dominated discipline. This paper addresses important issues. The first issue is a better understanding of the ascent of two women as Chief Executives of a patriarchal system. The second issue is to increase understanding of how gender is constructed and functions in social, cultural, historical, and institutional contexts, particularly as they intersect with political leadership roles. The thesis of this study is that class, political ambition, and political adroitness are more important than gender and social construction in determining the rise of women to high political office. The work implies that women at the higher end of the social stratum have a significant advantage over men and women at the lower end of the social stratum.
\end{abstract}

\section{Keywords}

Constructivism, feminism, class, political ambition, political adroitness

The year 1042 was otherwise unremarkable. There were no Magna opera written that year, or major breakthroughs in literature, the theater, religion, or philosophy. People witnessed no startling advances in the visual arts music, science, or technology. Typical political changes did take place. Edward the Confessor became king of England and Magnus the Good was crowned king of Denmark. Meanwhile, the Seljuk Turks were establishing an empire. The coronation of monarchs and the rise and decline of empires were not unusual in antiquity or the Middle Ages. However, on April 19, 1042, an unprecedented event occurred that never has been repeated-Two sisters became joint rulers of an organized state. The organized state under study is the Byzantine Empire ${ }^{1}$.

The names of the two sisters were Zoe and Theodora Porphyrogenita. The sisters ruled the Eastern Roman Empire (Byzantine Empire), the successor state to the Roman Empire, from its capital at Constantinople (modern Istanbul). During the
Roman Republic (509-27 B.C.), two men ruled as consuls. The consulship was the highest office of executive authority during the Republic. In theory, the consuls were equal in governance. However, in reality, one consul usually dominated the government by force of personality. For example, in 59 B.C., Gaius Julius Caesar and Marcus Calpurnius Bibulus were elected Consuls. Caesar controlled the affairs of state so completely that year that the Roman historian Gaius Suetonius sarcastically called the government "the Consulship of Julius and Caesar" (Suetonius Tranquillus 1989: 19-20). No woman served as Consul during the Roman Republic or as emperor during the Western Roman Empire. However, class

aTexas Woman's University, Denton, Texas, USA

\section{Correspondent Author:}

Valentine J. Belfiglio, 11505 Sonnet Drive, Dallas, Texas 75209, USA 
mattered. Julia Soaemias and Julia Maesa were the mother and grandmother respectively of the Western Roman Emperor Antoninus Heliogabalus (A.D. 218-222). The emperor appointed the two women to the previous all-male Roman Senate (Lampridius 1976). The joint rule of Zoe and Theodora over the Eastern Roman Empire was a unique event in the history of humankind. The purpose of this paper is to explore the factors that allowed two sisters to become potentates of an empire. The thesis of this study is that class and political adroitness trump social construction, environment, and gender in determining the rise of women to high political office.

\section{SCOPE AND METHOD}

The methodology employed in this paper is a Configurative-Ideographic case study based on biographical sketches of Zoe and Theodora Porphyogenita within the context of the political realities of the eleventh century Byzantine Empire, and constructivism and feminist international relations theory. This is a topic that needs addressing for two reasons. The first reason is to better understand the ascent of two women as Chief Executives of a patriarchal political system to demonstrate that gender is a systematic social construction of masculinity and femininity that is little, if at all, constrained by biology, and that class matters more than constructivism and feminist international relations theory (Harding 1987: 1-14). The second reason is to increase understanding of how gender is constructed and functions in social, cultural, historical, political, and institutional contexts, particularly as they intersect with political leadership roles.

\section{REVIEW OF THE LITERATURE}

Three classical works were useful to this study. The first work is by Michael Psellus (A.D. 1018-1096), Byzantine philosopher, historian, and man of letters.
Psellus wrote a history of the Byzantine Empire from Basil II (976-1025) until Michael VII (1071-1078). The second work was written by John Skylitzes (1040s-1101) who produced a synopsis of Byzantine History from 811-1057. He provides the only surviving continuous narrative of the late tenth and early eleventh centuries. Georgius Cedrenus (eleventh century) wrote the third classical work used in this study. Little is known about the background of Cedrenus, but his Corpus Scriptorum Historiae Byzantinae contains valuable information about Zoe and Theodora Porphyrogenita ${ }^{2}$. Scores of books, articles, and other secondary sources written in French, German, and English about the Byzantine Empire exist. The researcher has chosen to use in this work those books and articles well-documented through citations which demonstrate that the individual paragraphs of the secondary sources have been well-researched. Extensive bibliographies imply that authors have an adequate understanding of the current available literature. However, only full citations can verify and substantiate that the various pages of the articles or books are based on evidence, facts, data, informational input, or other intellectual raw materials.

\section{THE EASTERN ROMAN EMPIRE (BYZANTINE EMPIRE)}

In A.D. 330, the Roman Emperor Constantine I (c. A.D. 285-337) founded the new capital of the Roman Empire on the site of an ancient Greek city named Byzantium. He recognized the need for a new capital to replace Rome, which could no longer serve as the center of defense for the widely spread frontiers on the Rhine and Danube rivers and in the East. However, the empire was later divided into two parts to facilitate administration and defense. In 364, Valentinianus I ruled the western portion from Rome and Valens ruled the eastern portion from Constantinople, located on both sides of the Bosporus strait, in modern Turkey. In 
402, the Western Emperor Honorius moved the capital of the Western Empire to Ravenna because its marshes made it less vulnerable to attack and its port invulnerable to sieges (Heather 2013: 51).

In 476, Odoacer (c. 433-493), a German chieftain, displaced Romulus Augustulus, ending the Roman Empire in the West. There were strong efforts to restore the Western Empire by military means during the reign of Emperor Justinian I (427-565), but initial successes in recapturing Rome were only temporary. Logistical problems did not allow the Romans to maintain control over northern Italy, which the Lombard subdued (c. 568) (Procopius of Caesarea 1914-1935). In an attempt to restore the rule of law in the West, in 800, Pope Leo III crowned Charlemagne (Charles I), a Frankish king, as Emperor of the Holy Roman Empire. There was an attempt to reunite the Western and Eastern empires through marriage between Charlemagne and Irene, but Irene refused the proposal (Theophanes 2006). The core of the Eastern Empire was Asia Minor and the South Balkan Peninsula. Foreign invaders from many lands attacked the Eastern Empire, whose boundaries shifted according to military and diplomatic successes and failures, and the strength of the central government (Treadgold 1995: 14). In the eleventh century, the Seljuk Turks of the Abbassid caliphate posed the most serious military threat to the Eastern Empire (Harris 2010: 3).

From the time of Constantine I to the eleventh century, Byzantine culture experienced profound changes. The Greek language largely replaced Latin as the official language of the empire, and the influence of Asian culture was commonplace. Doctrinal disputes and diverging traditions created a cleavage between the Roman Catholic Church at Rome and the Eastern Orthodox Church at Constantinople. In 1054, the cleavage became permanent. Unlike the Western Empire, Roman women could rise to the highest political office in the East. From 797 to 802, Irene Sarantapechaina (c. 752-803) (Irene of Athens) ruled as the first woman potentate of the Byzantium Empire ${ }^{3}$.

The military also underwent significant structural and tactical changes between the founding of Constantinople and the eleventh century. In 1025, the total Byzantine army stood at about 250,000 men, and its navy hosted 300 warships (Treadgold 1995: 85). The 5,000 man legion of the Western army under the command of a legatus was replaced by a 9,600 man thema under the command of a strategos. The emperor (basileus) appointed all high ranking military officers. The basic strength of the Eastern Empire lay in its disciplined heavy cavalry. The cataphract of the Byzantine Empire symbolized the power of Constantinople in the same way that the legionary had represented the might of Rome. Cataphracts, and their horses in the front rank wore armor. The cataphract carried a bow and arrows, a long lance, a broadsword and dagger, and sometimes an ax. These were shock and awe troops. Lighter armored cavalrymen, armed primarily with bows and javelins, provided speed and mobility to the battle. The infantry was also divided into heavy and light classes. Most of the light infantrymen were archers and javelineers. The infantry and cavalry were combined for military campaigns in about equal proportions (Treadgold 1995: 87-117). The navy was made up of relatively small, light, and fast galleys with two banks of oars. Sailors and marines employed an incendiary weapon called Greek fire. It could be sprayed on enemy ships from bow tubes to great effect, as it would continue to burn while floating on water. Greek fire could also be hurled at ships from hand launchers or at greater distances by catapults (George 1998: 28-30).

The Byzantine Empire was a complex political system. In theory, the emperor (basileus) was a potentate who ruled by divine right. There were no political parties, and the emperor appointed all imperial judges (domestikos). The decisions of the imperial judges could be overruled by the emperor, and enactments by the emperor were the main source 
of law. Although primogeniture played a role in the selection of emperors, there were powerful people and institutions, which alone or in combination could depose an emperor, or block his accession (Kaldellis 2015: 102-117). Ambitious relatives within the imperial family could rebel against or assassinate an emperor. The Byzantine Senate and its president (proedros) could influence the choice of a new emperor, particularly during dynastic changes. High ranking military officials such as the imperial guard (spatharios) or overall commander of the army (megas domestikos) could stage a military coup. The Patriarch of Constantinople crowned all new emperors. The patriarch and his bishops had considerable influence over the political elite and the population of the empire. The general will of the people was essential to the stability of the regime. Revolution by the masses (politeia) was possible when an emperor ruled in a tyrannical manner. Perceptions of public opinion exerted considerable pressure on imperial actions. The imperial bureaucracy could also influence events. The emperor depended upon bureaucrats (logothetes) for information, advice, and carrying out public policy on a daily basis (Kaldellis 2015: 139-164). A final threat to the emperor was foreign enemies bent on conquest of the empire.

\section{EMPRESSES ZOE AND THEODORA PORPHYROGENITA: BIOGRAPHICAL SKETCHES}

Zoe (c. 978-1050) and Theodora (980-1056) Porphyrogenita were born in Constantinople. They were joint empresses (basilissae) of the Eastern Roman Empire from April 19-June 11, 1042. The sisters were the daughters of Emperor Constantine VIII and his wife Helena. Constantine VIII was born in 960 and died in 1028. Constantine served as emperor from 1025-1028. There is less known about Helena. Psellus writes that her father Alypius was a leading man in Constantinople and of a noble family.
Helena "was not only beautiful but also virtuous" (Psellus 1966). The three ancient writers used in this study agree that Emperor Constantine VIII was more interested in sensual pleasures and games than leading an empire. However, during his reign, the Roman army repulsed invasions by the Arabs and Patzinaks. The Patzinaks were semi-nomadic Turkic people of the Central Asian Steppes. The army also conducted a successful campaign against the Abasges-people inhabiting the western rim of the Black Sea (Psellus 1966; Skylitzes 2011; Cedrenus 1828).

Zoe and Theodora had an older sister named Eudokia. She was born in 976, and dedicated her life in service to God as a nun (Psellus 1966). Zoe and Theodora were brought up in the palace at Constantinople, "and educated in a manner worthy of their exalted rank" (Psellus 1966). They doubtless had the best tutors available. There is no reliable information about the early experiences of Eudokia, Zoe, and Theodora. There must have countless banquets, court ceremonies, and instructions about court etiquette, manners, and decorum. There would have been ample time for recreation, games, picnics, Byzantine music, Greek plays, and attending chariot races at the Hippodrome of Constantinople. They may have been associated with the daughters of aristocrats and visited the shops of the city under the protection of the palace guard. Travelling abroad would have been dangerous and arduous. As eligible imperial princesses, they probably received instructions about the duties and responsibilities of the throne. There were no male heirs to the throne. Therefore, as the eldest eligible daughter, Zoe became empress and married Romanos III Argyros, the urban prefect of Constantinople, in the imperial chapel of the palace on November 10, 1028. On November 12, they became rulers of the empire (Skylitzes 2011).

Zoe and Theodora's professional careers were in imperial politics. Zoe served as regent or co-emperor to five emperors between 1028 and 1050. Theodora co-reigned with two emperors and as sole ruler of the 
Byzantine Empire from 1055-1056. During their short reign together, Zoe was the senior empress and Theodora the junior empress. During their rule, they curbed the sale of public-offices and focused on the administration of justice. Zoe replaced incompetent rulers with officials based on merit. She appointed Nicolaus to high office in the east and Constantine Cabasilas in the west. George Maniaces became magister (a high court official) and was sent back to Italy as supreme commander of Byzantine holdings in southern Italy (Cedrenus 1828: 541). Mindful of the importance of the Senate and general will of the people, Zoe and Theodora rewarded the Senate with promotions and honors. They were generous with their distribution of gifts to the people. Skylitzes wrote: "The administration found itself conducted with befitting foresight" (Skylitzes 2011). Zoe settled lawsuits, acted in the public interest, cut military expenditures, held audiences with foreign ambassadors, and settled controversies between opposing factions. Psellus wrote that "both military and civil (authorities) ... treated the empresses with all due honor" (Psellus 1966). Theodora served as sole potentate of the Byzantium Empire from 1055-1056.

Theodora ruled the empire well. Her experiences as junior emperor under Zoe were useful to her. She appointed officials, dispensed justice from the throne, and issued decrees. There were no conspiracies against the government and the empire prospered. The harvest was abundant, no Roman territory was plundered and there was no open warfare. Theodora was most careful in matters concerned with religion. As she grew older, fearing for the empire's future welfare, she recommended Michael VI as her successor (Psellus 1966).

Neither Zoe nor Theodora served in the military nor other public service other than those already mentioned. Regarding professional, civic, and social memberships or activities, Zoe spent considerable time with the development of new perfumes or cosmetic ointments (Psellus 1966). Both sisters were devout members of The Byzantine Orthodox Church. The doctrines of the Church emphasized Christ's resurrection, rather than His crucifixion and that the Holy Spirit precedes from God the Father only. The Byzantine Orthodox Church opposed the worship of relics (Psellus 1966). Zoe married three times. These spouses include: Romanos III (1028-1034), Michael IV (1034-1041), and Constantine IX (1042-1050) (Skylitzes 2011). Romanos III was a mediocre ruler. He accomplished nothing significant in domestic policy and suffered a disastrous defeat at Azaz after leading a large army against the Mirdasids of Aleppo (Skylitzes 2011). Zoe never loved Romanos, and took a lover in Michael IV the Paphlagonian. She slowly poisoned Romanos with a mixture containing hellebore, and when the process took too long for the impatient lovers, Michael's friends strangled and drowned Romanos in his bath (Cedrenus 1828: 505). Zoe and Michael married on April 11, 1034, the day of the assassination. On the next day, Alexios I, Patriarch of Constantinople crowned Michael IV as the new emperor. During his reign, the Byzantine army and their allies faced a number of military engagement along the Anatolian and North African coasts, on the island of Messina, and in Bulgaria. Michael left the governance of domestic policy to his brother John (Skylitzes 2011).

If Zoe expected gratitude from Michael, she was sadly mistaken. If she had been familiar with the writings of the famous Roman poet, Gaius Valerius Catullus (87-54), she might have remembered his sage advice: "Desine de quoquamquicquam bene vellemereri, autaliquemfieri posse putarepium"4. Upon becoming emperor, Michael excluded Zoe from imperial politics altogether, and confined the empress to the gynaeceum, a section of the imperial palace reserved for women (Skylitzes 2011). In spite of this, Zoe seemed to continue to love Michael. Skylitzes wrote that "she passionately desired to a child" (Skylitzes 2011). However, she was 56 when they married and probably past menopause. Therefore, Zoe 
adopted Michael Calaphates, the future Michael V in 1040 (Psellus 1966). Michael IV died on December 10, 1041 of an unknown disease (Skylitzes 2011).

On December 10, 1041, Michael V ascended to the throne. He was 26 years old, the son of Maria, a sister of Michael IV and Zoe, adopted son. He studied the political situation in Constantinople, and played his role well. Then on April 18, 1042, he expelled Zoe from the palace and sent her into exile on the Island of Prinkipo in order to assume full control of the Byzantine Empire (Cedrenus 1828: 537). This move infuriated the general will of the people and caused a revolution (Psellus 1966). Michael abdicated and Zoe and Theodora ascended to the throne as co-emperors (Psellus 1966). Military officials arrested Michael, blinded him, and sent him into exile. He died a monk in the monastery of Elegmoi, Bithynia, on August 24, 1042 (Skylitzes 2011). Zoe married Constantine IX Monomachos, a Byzantine judge in Greece, on June 11, 1042. On the following day, Constantine was formally proclaimed emperor together with Zoe and Theodora (Psellus 1966). Constantine cut the military budget to the point that it had dire long-term consequences for the Byzantine Empire. In 1053, the army of the Normans, under the command of Robert Guiscard (1015-1085) conquered southern Italy and established Norman control there. The Byzantines lost Asia Minor to the Turks after the Battle of Manzikert in 1071, even though Constantine was no longer emperor. During that year, the Normans conquered the remaining Byzantine territories in Italy. Although the Byzantine Empire had some military successes during Constantine's reign, most of the state treasury went to civilian officials who governed the territories. Different generals revolted in 1043 and 1047, but they failed to achieve a military coup. Constantine died on January 11, 1055, and Theodora became sole empress (Skylitzes 2011).

Zoe and Theodora Porphyrogenita lived in Constantinople all of their lives. Zoe Died in Constantinople in 1050 during the reign of
Constantine IX, after a short and painful illness (Psellus 1966). Theodora also died in Constantinople on August 31, 1056 of an intestinal disease (Psellus 1966). The Byzantine Empire continued to exist for almost another 400 years after the death of Theodora. On May 29, 1453, the Ottoman Turks, led by Mehmed II, seized Constantinople in 1453 (Harris 2010: 196-206). The Holy Roman Empire collapsed in 1806.

\section{CONCLUSIONS}

This study has focused on a unique event in the history of humankind. Zoe and Theodora Porphyrogenita were the only two sisters to jointly rule a state. How did this unequaled event occur? There are several reasons. The first reason is that Irene Sarantapechaina (c. 752-803) (Irene of Athens) (Irene the Athenian) paved the way for other women rulers as the first woman potentate of the Eastern Roman Empire. She ruled the empire from 797 to 802 . The second reason is that Zoe and Theodora's father Constantine VIII and his wife Helena had no sons, and primogeniture during dynasties was an important factor in the selection of emperors. A third reason is that key members of the court, palace, and nobility decided that Zoe needed a co-ruler, and that it should be her sister Theodora. The fourth reason is that the Senate, the ruling elite, and the people knew that the sisters were generous in granting rewards, gifts, promotions, and honors. The final reason for the ascension of Zoe and Theodora is that they were highly intelligent, grasped the political dynamics of leadership backgrounds, functioned fairly effectively within their changing political roles, and stayed on the political offensive. They were successful enough to allow another woman potentate to rule the Byzantine Empire. Yolande, a Latin empress, ruled from 1217 to 1219.

The findings of this study challenge the theory that constructivism or gender determines the role of women within a political system. The experiences of 
Zoe and Theodora suggest that class and political adroitness trump social construction, environment, and gender in determining the rise of women to high political office. Women at the higher end of the social stratum have a significant advantage over women and men at the lower end of the social stratum.

\section{Notes}

1. McKay, J. P., B. D. Hill, J. Buckler, and P. B. Ebrey. 2004. A History of World Societies. New York: Houghton Mifflin. Pp. 252, 377-380. For the purposes of this study, "state" means "a political community occupying a definite territory, having an organized government, and possessing internal and external sovereignty...". The definition also includes "recognition of a claim to independence by other states, enabling it to enter into international engagements". See Plano, J. and M. Greenberg. 1973. Political Science Dictionary. Hinsdale, Illinois: The Dryden Press. P. 360.

2. Psellus, M. Chronographia. 1966. Translated by E. R. A. Sewter. New York: Penguin Classics; Skylitzes, J. 2011. Synopsis Historia Byzantina: 811-1057, Tomus Secundus. Translated by J. Wortley. Cambridge, England: Cambridge University Press; Cedrenus, G. 1828. Corpus Scriptorum Historiae Byzantinae. Translated from Greek to Latin by B. G. Niebuhr. Bonnae: E.D. Weber. Dawkins Collection, Library of the Taylor Institution, Department of Byzantine and Modern Greek, University of Oxford, Oxford, England.

3. Theophanes (AM 6289, AD 796/797)-(AM 6295, AD 802/803).

4. "Cease to expect to win men's gratitude, to think that human beings can be grateful". Catullus, G. V. 1909. Carmina. Translated by G. Long. New York: PF Collier. Catullus, Carmina, lxxiii. 406.

\section{References}

Catullus, G. V. 1909. Carmina. Translated by G. Long. New York: PF Collier.

Cedrenus, G. 1828. Corpus Scriptorum Historiae Byzantinae (Corpus of Byzantine History Writers). Translated from Greek to Latin by B. G. Niebuhr. Bonnae: E.D. Weber.

George, J. E. 1998. History of Warships: From Ancient Times to the Twenty-First Century. Annapolis, Maryland: Naval Institute Press.

Harding, S. 1987. "Introduction: Is There a Feminist Methodology?" Pp. 1-14 in Feminism and Methodology, edited by S. Harding. Bloomington: Indiana University Press.

Harris, J. 2010. The End of Byzantium. New Haven, Connecticut: Yale University Press.

Heather, P. 2013. The Restoration of Rome: Barbarian Popes and Imperial Pretenders. Oxford, England: Oxford University Press.

Kaldellis, A. 2015. The Byzantine Republic: People and Power in New Rome. Cambridge, Massachusetts: Harvard University Press.

Lampridius, A. 1976. “Antoninus Heliogabalus.” The Augustan History. New York: Penguin Books.

McKay, J. P., B. D. Hill, J. Buckler, and P. B. Ebrey. 2004. A History of World Societies. New York: Houghton Mifflin.

Plano, J. and M. Greenberg. 1973. Political Science Dictionary. Hinsdale, Illinois: The Dryden Press.

Procopius of Caesarea. 1914-1935. History of the Wars. Translated by H. B. Dewing. London: William Heinemann.

Psellus, M. 1966. Chronographia. Translated by E. R. A. Sewter. New York: Penguin Classics.

Skylitzes, J. 2011. Synopsis Historia Byzantina: 811-1057, Tomus Secundus (A Synopsis of Byzantine History, 811-1057: Translation and Notes). Translated by J. Wortley. Cambridge, England: Cambridge University Press.

Suetonius Tranquillus, G. 1989. The Twelve Caesars. Translated by R. Graves. New York: Penguin Books.

Theophanes. 2006. The Chronicle of Theophanes Confessor: Byzantine and Near Eastern History AD 284-813. Translated by C. Mango and R. Scott. Oxford: Clarendom Press.

Tranquillus, G. S. 1989. The Twelve Caesars. Translated by R. Graves. New York: Penguin Books.

Treadgold, W. 1995. Byzantium and Its Army: 284-1081. Stanford, California: Stanford University Press.

\section{Bio}

Valentine J. Belfiglio, Ph.D., educator of international relations and diplomatic history, Department of History and Government, Texas Woman's University, Denton, Texas, USA; research fields: diplomatic history, women's studies, ancient Roman history. 